\title{
MEMFUNGSIKAN MASJID SEBAGAI TEMPAT PENDIDIKAN ISLAM
}

\author{
Wage \\ Universitas Muhammadiyah Purwokerto, Email : wagefsyah.2010@gmail.com
}

\begin{abstract}
ABSTRAK
Penelitian ini bertujuan untuk mendeskripsikan kegiatan pendidikan Islam yang dilakukan di masjid Al-Huda Tambaksogra kecamatan Sumbang, kabupaten Banyumas, Jawa Tengah. Selain itu penelitian juga bertujuan untuk mengetahui factor-faktor keberhasilan pendidikan islam di Masjid Al-Huda. Penelitian ini termasuk jenis penelitian kualitatif. Pendekatan yang digunakan adalah study deskriptif. Subjek penelitian adalah takmir masjid Al-Huda, para ustadz dan para pelaku sejarah yang masih hidup. Pengumpulan data dilakukan dengan metode dokumentasi dan wawancara. Sedangkan metode analisis data menggunakan metode induktif dengan model penguraian deskriptif analitis. Hasil penelitian menunjukkan bahwa masjid Al-Huda Tambaksogra memainkan peranan sebagai lembaga pendidikan Islam yang efektif. Hal itu terlihat dari banyaknya hasil pendidikan Islam yang telah diraih di antaranya diamalkannya Rukun Iman dan Rukun Islam dengan baik. Selain itu jama'ah shalat yang selalu membludag dalam setiap waktu shalat, dilaksanakannya infak, ibadah qurban, tadarus al-Quran, shalat dan puasa sunah serta sunatan massal dan pawai ta'aruf islam serta akhlak masyarakat yang tergolong baik. Faktor-faktor yang mendukung keberhasilan pendidikan islam di masjid Al-Huda di antaranya adalah faktor sejarah, faktor keteladanan, faktor metode dan faktor kekompakan para tokohnya.
\end{abstract}

Kata-Kata Kunci : Pendidikan Islam, Masjid Al-Huda, Fungsi/Peranan Masjid, Ta'mir Masjid

\begin{abstract}
This study aims to describe Islamic education activities carried out at Al-Huda Tambaksogra mosque in Sumbang sub-district, Banyumas district, Central Java. In addition, the study also aims to determine the factors of success in Islamic education at the Al-Huda Mosque. This research is a type of qualitative research. The approach used is descriptive study. The research subjects were takmir of the Al-Huda mosque, clerics and surviving historical actors. Data collection is done by the method of documentation and interviews. While the method of data analysis uses inductive methods with analytical descriptive decomposition models. The results showed that the Al-Huda Tambaksogra mosque played a role as an effective Islamic education institution. This can be seen from the many results of Islamic education that have been achieved including the implementation of the Pillars of Faith and the Pillars of Islam well. In addition, congregational prayers are always open in every prayer time, the implementation of infaq, qurban worship, tadarus al-Quran, prayers and fasting of the sunnah and mass circumcision and Islamic parade of ta'aruf and good moral character. The factors that support the success of Islamic education in the Al-Huda mosque include historical factors, exemplary factors, method factors and the compactness factor of the characters.
\end{abstract}

Keywords : Islamic Education, Al-Huda Mosque, Function / Role of the Mosque, Ta'mir Masjid 


\section{Islãmadîna \\ JURNAL PEMIKIRAN ISLAM}

\section{PENDAHULUAN}

Berbicara tentang masyarakat Islam, maka harus dilihat fungsi masjid. Sudah terbukti dalam sejarah bahwa dari masjidlah lahir peradaban Islam. Ketika Rasulullah SAW hijrah ke Madinah, begitu tiba di Quba' maka langkah pertama yang dilakukannya adalah membangun masjid kecil. Dari masjid kecil inilah di kemudian hari terbangunnya suatu peradaban besar. (Abdullah Idi dan Toto Suharto, 2006: 79). Setelah tiba di Madinah maka langkah selanjutnya adalah membangun masjid Nabawi. Di masjid inilah beliau memulai membangun masyarakat Islam, masyarakat baru yang berlandaskan tauhid, menyatukan Muhajirin dan Anshar. (Ramayulis, 2012: 27-28). Dari masjidlah lahir para pemimpin Islam. Mengapa demikian? Karena di masjidlah pendidikan dilaksanakan bagi masyarakat Islam. Kita lihat bagaimana Rasulullah SAW dahulu memulai pedidikan mental dan fisik para pengikutnya di masjid. (Mujamil Qomar, 2014: 177).

Permasalahnya adalah belum semua masjid dapat menjalankan fungsi sebagaimana mestinya. Bahkan kebanyakan masjid hanya menjalankan salah satu fungsinya saja, yaitu sebagai tempat ibadah. Itu saja belum maksimal. Masih banyak ditemukan masjid yang terlihat rusak, kumuh, sepi dan merana, yang mengindikasikan tidak adanya pengelolaan yang benar dan baik. Sementara masjid yang terlihat mentereng dan ramai dikunjungi orang pada jam-jam shalat, namun di situ belum terlihat adanya kegiatan lain. Ada juga masjid yang di samping untuk shalat juga untuk pengajian atau madrasah diniyah, namun berhenti sampai di situ. Jadi amat jarang masjid dengan kegiatan yang lengkap, baik untuk pendidikan keimanan maupun implementasi berbagai ajaran Islam.

Bila masjid-masjid tidak berfungsi sebagaimana mestinya, tentunya sulit diharapkan adanya implementasi ajaran Islam dengan baik. Hal itu menuntut tanggung jawab para tokoh Islam, termasuk para sarjananya, bagaimana masjid dapat berfungsi dengan baik. Salah satu cara yang munkin ditempuh untuk memberdayakan masjid adalah dengan mempublikasikan kisah sukses masjid-masjid yang sudah baik dalam mengelola pendidikan, dakwah dan implementasi ajaran Islam dalam berbagai aspeknya agar hal itu bisa diketahui dan ditiru masjid-masjid lain, sehingga semakin banyak masjid yang berfungsi sebagaimana mestinya. Dari sekian banyak masjid yang berfungsi dengan baik sebagai pusat pndidikan dan dakwah serta implementasi beberapa ajaran Islam adalah masjid Al-Huda yang beralamat di RT 04 RW 03 desa Tambaksogra, kecamatan Sumbang, kabupaten Banyumas. Di masjid tersebut kegiatan pendidikan dan dakwah tampak lebih menonjol dibanding masjid-masjid lain di Banyumas. Hal itu terlihat dari beberapa hal, misalnya jumlah jama'ah yang shalat lima waktu selalu dalam jumlah yang banyak, pengajian rutin berjalan dengan baik, kegiatan TPA/TPQ dikelola dengan rapi. Memiliki balai pengobatan, perpustakaan, gedung TPQ/TPA yang representative, dan tidak lupa ada kamar mandi dan WC yang memadai. Setiap hari raya Qurban 


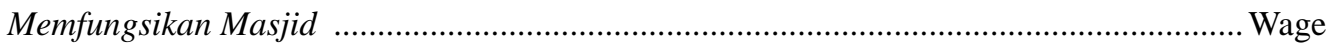

menyembelih hewan qurban dalam jumlah banyak sehingga masyarakat menerima bagian daging qurban dalam jumlah berlimpah, zakat maal berjalan baik, setiap momen hari besar Islam selalu diisi dengan berbagai kegiatan keislaman seperti tabligh akbar, karnaval, khitanan masal dsb.

Kesuksesan pendidikan Islam dan dakwah perlu diteliti, untuk mengetahui rahasia sukses yang ada di belakangnya. Dari hasil penelitian yang ada kemudian dipublikasikan sehingga dapat diakses oleh umat Islam di tempat lain sebagai bahan rujukan, minimal referensi, bagaimana sebaiknya melakukan pendidikan Islam dan dakwah yang berpusat di masjid. Secara bahasa, masjid berarti tempat sujud (Glase, 2002: 262). Kata sujud, menurut beberapa ayat al-Quran yang penulis himpun, mengandung beberapa pengertian, pertama, pengakuan dan penghormatan kepada pihak lain - seperti sujudnya Malaikat kepada Adam- (QS Al-Baqarah (2): 30). Kedua, kesadaran kepada kekhilafan diri sendiri serta pengakuan atas kebenaran pihak lain - seperti sujudnya para tukang sihir raja Fir'aun setelah nabi Musa menunjukkan mukjizat dan mengalahkan sihir mereka - (QS Thaha (20): 20). Ketiga, sujud berarti mengikuti dan menyesuaikan diri dengan ketetapan Allah/sunnatullah misalnya sujudnya binatang, tetumbuhan dan sebagainya (QS Ar-Rahman (55): 55). Dari beberapa arti di atas bila dikaitkan dengan arti masjid, yaitu tempat sujud, maka bisa difahami bahwa maksud dari kata sujud adalah dalam arti luas. Sujud adalah aktivitas untuk mengakui keagungan Tuhan, menghormatiNya, pengakuan atas kesalahan diri-sendiri dan ke MahasucianNya dari kesalahan, dan sujud juga berarti pernyataan ketundukan terhadap semua aturan Allah SWT.

Menurut istilah syara', masjid adalah suatu bangunan yang merupakan tempat ibadah umat Islam, yang biasanya digunakan untuk melaksnakan shalat jama'ah (Ensiklopedi Hukum Islam, 2000: 1119). Ada yang membedakan masjid dari mushala, misalnya dinamakan masjid kalau dipergunakan untuk shalat Jum'ah, sedangkan mushala tidak. Ketika membicarakan fungsi masjid, Quraish Shihab merujuk pada surat An-Nur (31) : 36-37. Ayat tersebut menjelaskan bahwa fungsi masjid adalah untuk bertasbih. Maksud tasbih dalam ayat itu bukan dalam arti sempit mengucapkan lafadz "subhanallah", namun lebih luas lagi, yaitu taqwa (Shihab, 1996: 461). Secara umum fungsi masjid adalah untuk melaksanakan taqwa (Maulana Muhammad Ali, 2007: 485). Pada umumnya ulama menerjemahkan taqwa dengan "melaksanakan segala perintah Allah dengan penuh ketaatan, dan menjauhi segala laranganNya berupa maksiat dan kejahatan" (Hasyim, 2007: 618). Dalam konsep Islam, taqwa merupakan predikat tertinggi, karena merupakan akumulasi dari iman, islam dan ihsan (Ilyas, 2002: 18-20)

Jika dihubungkan dengan peristiwa Isra'-Mi'raj yang dilakukan oleh Rasulullah SAW, di mana hasilnya adalah diwahyukannya perintah shalat yang merupakan ibadah terpenting dalam Islam, maka menurut al-Quran Isra'-Mi'raj adalah perjalanan dari masjid ke masjid (QS Al-Isra (17) : 1). Hal itu 


\section{Islãmadîna \\ JURNAL PEMIKIRAN ISLAM}

menunjukkan betapa pentingnya peranan masjid dalam Islam; ia merupakan tempat berangkat (memulai aktivitas) umat Islam, sekaligus merupakan tempat kembali (mengakhiri aktivitas). Masjid merupakan tempat untuk merancang kesuksesan umat dalam peradaban mereka. (Hafidhuddin, 2003: 462). Berdasartkan penelitian Abbasali, masjid memiliki keunikan jika dibanding dengan tempat ibadah agama lain. Jika tempat agama lain hanya dipergunakan untuk kegiatan khas keagamaan (ibadah mahdlah, menurut istilah Islam) maka masjid memiliki fungsi amat luas. Ia tidak hanya berfungsi sebagai tempat kegiatan keakhiratan, anmun juga untuk berbagai kegiatan keduniaan (Farahati Abbasali,2011)

Pada jaman Rasul SAW masjid berfungsi untuk berbagai kegiatan. Suryadharma Ali menyatakan bahwa waktu itu masjid merupakan tempat untuk; 1) ibadah (shalat); 2) pusat pendidikan dan pengajaran; 3) pusat peradilan; 4) pusat pemberdayaan ekonomi umat ; 5) pusat informasi; 6) pusat latihan militer dan pemerintahan (Suryadharma Ali, 2013). Menurut Ramayulis (Ramayulis: 18 dst), fungsi seperti itu bukan hanya untuk zaman Rasul, namun juga pada zaman sesudahnya yaitu era keemasan Islam, khususnya untuk masjid besar. Menurut Abdeh (2011: 1), fungsi masjid seperti terjadi di jaman rasul SAW merupakan fungsi universal yang mestinya terus dipelihara, yaitu masjid sebagai tempat ibadah, tempat kebudayaan dan pendidikan, tempat pelayanan umum bidang kesehatan dan santunan sosial. Dalam Ensiklopedi Hukum Islam (2000: 1120) dinyatakan bahwa zaman dahulu masjid berfungsi untuk kegiatan sosial seperti dakwah, pendidikan, serta berfungsi politis, yaitu sebagai pusat pemerintahan, administrasi Negara dan berbagai permusyawaratan bidang politik. Menurut Shihab, sekarangpun mestinya masjid besar bisa berfungsi seperti itu. Untuk itu dia menyarankan agar dalam membangun masjid dilengkapi berbagai sarana agar dapat berfungsi sebagaimana mestinya serta memiliki daya tarik bagi semua kalangan (Shihab, 1996: 463)

Hasil penelitian penulis terhadap beberapa ayat yang berkaitan dengan masjid, di mana penelitian menggunakan kamus pembuka al-Quran "Fath Arrahman" (Al Maqdisi, t.th) menghasilkan kesimpulan tentang fungsi masjid sebagai berikut: pertama, sebagai tempat bagi manusia untuk menghadapkan diri kepada Allah SWT melalui kegiatan shalat yang dilakukannya (QS Al-A'raf (7) : 29, QS Al-Jin (72) : 18, QS Al-Baqarah (2) : 114). Kedua, sebagai tempat I'tikaf (QS Al-Baqarah (2) : 187). Sementara dari penelitian lapangan yang dilakukan Isgandarova (Nazila Isgandarova: 2009) terhadap beberapa masjid di Negara-negara non muslim (Barat) maka fungsi masjid adalah sebagai berikut: pertama, untuk shalat, baik munfarid maupun berjama'ah. Selain untuk shalat fardlu, masjid di sana dipergunakan untuk shalat Jum'ah dan 'Idain (hari raya Idul Fitri dan Idul Adha). Kedua, untuk pertemuan ilmiah. Berbagai masalah keislaman dikaji di sana secara terbuka, disediakan bagi siapa saja. Ketiga, untuk madrasah. Materi yang diajarkan adalah cara membaca al-Quran dan ajaran-ajaran dasar Islam. Keempat, untuk pengislaman. Di Jepang misalnya, Dr. Syauqi Futaki banyak mengislamkan penduduk asli Jepang. Kelima, untuk 


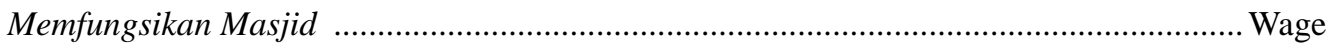

perpustakaan. Di Barat khususnya, masyarakatnya terbiasa gemar membaca, sehingga masjidpun dilengkapi dengan perpustakaan yang memadai. Keenam, untuk toko buku. Buku-buku yang dijual tentu saja buku tentang Islam, sebagaimana yang terjadi pada masjid di London, Paris dan lain-lain. Ketujuh, untuk pernikahan. Di semua masjid biasa di jadikan tempat pernikahan umat islam di Negara-negara itu. Kedelapan, objek turisme. Bagi umat non muslim di Negara-negara seperti itu masjid dan kegiatan umat Islam menarik untuk di perhatikan. Kesembilan, kafetaria. Kafetaria yang berada satu komplek dengan masjid biasanya menjual makanan kecil dan minuman halal. Ternyata yang mengunjungi bukan hanya kaum muslimin, contohnya kafetaria masjid di Paris.

Menurut Hentika (2016) masjid berfungsi sebagai pusat peribadatan-khususnya shalat- dan juga sebagai pusat kebudayaan Islam. Namun dia mendapati fakta bahwa ta'mir masjid menjadi kendala untuk mewujudkan hal tersebut disebabkan kurangnya wawasan keislaman, niat yang tidak tulus dan iman yang kurang kokoh. Auliyah (2014) menemukan fakta bahwa masjid At Taqwa Bangkalan Madura berperan aktif dalam pemberdayaan ekonomi umat dengan cara memberikan pinjaman modal usaha yang dananya berasal dari zakat, infak dan shadaqah kaum muslimin. Sofwan (2013) menyatakan bahwa masjid sebagai tempat pendidikan, maka bisa menyelenggarakan pendidikan membangun SDM di lingkungan masjid. Pendidikan itu bisa berupa : 1. Diklat ke-SDM-an di masjid termasuk diklat manajemen masjid 2. Diklat keagamaan di masjid melalui pengajian, majlis ta'lim dan pembinaan mental spiritual 3. Diklat peningkatan kualitas SDM dari segi fisik dan mental untuk meningkatkan kesejahteraan sosial Diklat kaderisasi Pengurus Pengelola untuk lebih memakmurkan masjid 5. Diklat Pengelolaan dan Pengembangan Keuangan Masjid.

Di Malaysia, masjid mendapat perhatian khusus dari pemerintah. Pemerintah Malaysia menetapkan kebijakan agar masjid dijadikan pusat pendidikan Islam, di samping fungsi-fungsi lainnya (Rahman, A Hj Abd, dkk , 2011). Idi dan Suharto (2006: 83) mengusulkan adanya revitalisasi masjid sebagai pusat pendidikan. Menurut penulis ini adalah usulan yang bagus, karena dalam catatan sejarah, peradaban Islam lahir dan berawal dari masjid. Pada masa awal sejarah Islam, masjid menjadi lembaga pendidikan utama. Waktu itu, masjid dengan segala sarana yang ada, dijadikan pusat pendidikan umat. Inilah yang dilakukan oleh Rasulullah SAW di masjid Nabawi. Peserta didiknya mencakup segala umur dan jenis kelamin. Bagi orang dewasa mereka mempelajari al-Quran, hadits, fikih, aqidah, bahasa dan sastra Arab. Sedangkan kaum wanita mereka mempelajari al-Quran, hadits, aqidah, menenun atau memintal, dengan frekuensi seminggu sekali. Sementara anak-anak belajar di serambi masjid dengan materi al-Quran, agama, bahasa Arab, berhitung, berkuda, memanah dan berenang (Idi dan Suharto, ibid: 81).

Dari sejarah dapat terlihat, kaum muslimin naik ke puncak peradaban 


\section{Islãmadîna \\ JURNAL PEMIKIRAN ISLAM}

dunia berawal dari masjid. Kemudian mereka jatuh dari sana karena menjauhi masjid. Hal ini menunjukkan bahwa masjid sejatinya merupakan pusat peradaban Islam. Oleh karenanya jika umat Islam ingin meraih kejayaan seperti masa lalu maka tidak ada jalan lain kecuali mereka harus memulainya dari masjid. Ini berarti, konsekuensinya masjid juga harus diperbaharui sarana-prasarana, manajemen pengelolaan, program-program dan fungsinya. (Idi dan Suharto, ibid : 83). Untuk menelorkan hasil pendidikan Islam yang maksimal masjid tidak berdiri sendiri, namun harus dipadukan dengan lembaga pendidikan lain. Dalam hal ini 'Ulwan (2012: 830-831) menyarankan adanya kerjasama antara rumah, masjid dan sekolah.

\section{METODE PENELITIAN}

Penelitian ini termasuk jenis penelitian kualitatif. Pendekatan yang digunakan adalah studi deskriptif. Peneliti akan mengumpulkan informasi sebanyak-banyaknya agar dapat mendeskripsikan permasalahan sejelas-jelasnya. Penelitian dilakukan di masjid Al-Huda, dusun Brobot, desa Tambaksogra, kecamatan sumbang, kabupaten Banyumas, Jawa Tengah. Subjek penelitian ini adalah para tokoh yang terlibat langsung dengan pendidikan Islam di masjid Al-Huda seperti takmir masjid, ustadz dan tokoh Islam lain (da'i) serta pelaku sejarah awal berdirinya masjid. Proses pengumpulan informasi menggunakan metode dokumentasi dan wawancara. Metode dokumentasi digunakan untuk mengetahui hal-hal yang sudah menjadi sejarah masa lalu seperti asal mula tanah wakaf masjid (sertifikat/girik tanah masjid) dan catatan-catan kegiatan takmir masjid dari waktu ke waktu. Metode wawancara digunakan untuk mencari data tentang sejarah pendidikan Islam masa lalu maupun yang sedang berlangsung. Metode analisis data menggunakan metode penyimpulan induktif, yaitu data-data yang sifatnya khusus ditarik ke dalam kesimpulan yang bersifat umum. Model penguraiannya dengan pendekatan deskriptif analitis.

\section{HASIL DAN PEMBAHASAN}

1. Kegiatan Masjid Kegiatan Pendidikan Islam di Masjid Al-Huda

Tokoh paling besar pengaruhnya dalam perkembangan Islam di dusun Brobot, desa Tambaksogra adalah kyai Jaelani dari Purwokerto, alamat persisnya di kompleks Sokajaya, Sokanegara, Purwokerto. Dialah mubaligh yang telah membentuk jiwa islami masyarakat Brobot sejak tahun 1950 an hingga 1990 an. Kegiatan dakwahnya yang tidak kenal lelah dan penuh dedikasi menjadikannya sosok yang diteladani. Ilmu agamanya tergolong mumpuni, karena dia merupakan lulusan dari beberapa pesantren. Di samping itu ketegasan dan keteguhannya dalam memegang prinsip serta kegigihannya dalam menjalankan ajaran agama menjadikan umat termotivasi untuk menjalankan apa yang diajarkannya. Boleh dikatakan dia merupakan orang paling berpengaruh di Brobot dalam menyebarkan Islam.

Setelah berhenti mengajar di Brobot dan wilayah Sumbang lainnya 


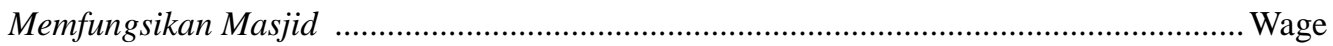

karena factor usia dan gangguan kesehatan, kegiatan dakwahnya dilanjutkan oleh para muridnya. Perlu diketahui bahwa selain murid yang mengikuti kajian yang diberikan di beberapa tempat di wilayah kecamatan Sumbang, kyai Jaelani juga memiliki murid setia yang secara rutin mengikuti kajian agama yang diselenggarakan di rumahnya. Murid yang berasal dari desa kecamatan Sumbang cukup banyak, di antaranya adalah yang berasal dari dusun Brobot seperti H. Narsum, Sahidi, SH, H. Hadi Sukarso, H. Sarwono, H. Sutrisno, H. Salam dan Waluyo. Para murid itulah yang meneruskan dakwah di Brobot setelah kyai Jaelani berhenti berdakwah.

Kegiatan pendidikan Islam yang diselenggarakan di Brobot dilihat dari segi sifatnya terbagi dua, pertama bersifat teoritik, dan kedua, bersifat praktik. Yang bersifat teoritik adalah pendidikan dalam bentuk pemberian materi ajar yang disampaikan dalam forum pengajian maupun di luar forum. Sedangkan yang bersifat praktik adalah pendidikan dalam bentuk santunan sosial atau syiar Islam.

Dilihat dari sasarannya pendidikan Islam di masjid Al-Huda tertuju pada tiga sasaran; pertama, untuk orang dewasa, kedua, untuk remaja, ketiga, untuk anak-anak dan keempat, untuk umum. Pendidikan Islam untuk dewasa bentuknya berupa pengajian. Ada dua macam pengajian untuk orang dewasa yaitu pengajian untuk kaum wanita dan pengajian umum. Pengajian untuk kaum wanita diadakan setiap malam Rabu, selepas Magrib hingga 'Isya, sedangkan pengajian umum diadakan setiap malam Sabtu - selepas Magrib hingga 'Isya dan Ahad pagi - selepas shalat Shubuh hingga jam 6 pagi. Pematerinya kebanyakan mubaligh local seperti H. Narsum, Amin Zaenuddin, Sahidi, SH, Waluyo, H. Sutrisno dan Hj. Murniati. Materinya tidak ditentukan oleh takmir, tetapi diserahkan kepada para mubaligh, kebanyakan materi bersifat motivasi pengamalan agama.

Pendidikan Islam untuk remaja ujudnya berupa pengajian atau diskusi keagamaan. Pesertanya adalah para remaja alumni TPQ Al-Huda yang rata-rata bersekolah di SLTP dan SLTA. Waktunya adalah setiap malam Minggu. Yang mengisi ada beberapa orang namun yang rutin adalah ustadz Arif Aji Setiawan S.Pd.I. Materinya berupa pendalaman fiqih dan al-Quran sebagai kelanjutan materi sewaktu di TPQ dahulu. Pendidikan Islam untuk anak-anak diselenggarakan dalam bentuk Taman Pendidikan Al-Quran (TPQ). Tempat belajarnya di gedung TPQ Al-Huda yang berlokasi di sebelah utara masjid Al-Huda (satu kompleks). Waktu belajarnya setiap hari mulai jam 15.30 sampai jam 17.30. Materi belajarnya al-Quran, Fiqih dan Aqidah. Pesertanya anak-anak usia Sekolah Dasar (SD) dari kelas 1 sampai kelas 6. Ustadznya antara lain Arif Aji Setiawan, S.Pd.I, Muksiah dan Ufi Sunarti. Selain bentuk pengajiaan ada lagi bentuk lain pendidikan Islam di sana yaitu khutbah Jum'ah, yang diselenggarakan setiap hari Jum'ah pada waktu khatib berkhutbah di atas mimbar. 


\section{Islãmadîna

Ada lagi bentuk pendidikan Islam yang lain yaitu praktek ibadah sosial dan syiar Islam. Ibadah sosial dimaksud ujudnya berupa pembagian dana ZIS, pembagian daging qurban, khitanan massal dan menjenguk orang sakit dan melahirkan. Sedangkan yang dimaksud pendidikan Islam berupa syiar Islam adalah kegiatan semacam pawai keliling setiap memperingati tahun baru Islam (tanggal 1 Muharram).

2. Hasil Pendidikan Islam Masjid Al-Huda

Dari pendidikan yang diselenggarakan di masjid Al-Huda maka lahirlah beberapa amaliyah keagamaan. Berikut ini merupakan amaliyah yang menonjol yang dihasilkan oleh pendidikan Islam di sana yakni: pertama, shalat jama'ah. Hasil dari pendidikan Islam di masjid Al-Huda yang sangat menonjol adalah shalat berjama'ah. Di masjid ini jumlah jama'ah yang melakukan shalat Lima Waktu tergolong luar biasa. Kelima waktu shalat (Shubuh, Duhur, 'Ashar, Magrib dan 'Isya) selalu terisi jama'ah dalam jumlah luar biasa jika dibanding dengan masjid lain di kecamatan Sumbang dan tempat lain. Kedua, puasa dan amaliyah Ramadlan. Ketika tiba bulan Ramadlan maka semarak umat Islam Brobot tampak luar biasa. Kegiatan pengajian bertambah banyak; ada pengajian menjelang buka puasa, pengajian menjelang shalat Tarawih dan pengajian setelah shalat Shubuh. Shalat Tarawih dilakukan dua shif, ada shif sore, yaitu setelah shalat Isya, dan ada shif malam, yaitu menjelang makan sahur. Shif sore biasa diikuti oleh remaja dan anak-anak, sedang shif malam diikuti oleh orang dewasa. Selain itu ada lagi kegiatan tadarus al-Quran yang dilaksanakan di masjid pada setiap malam sehabis shalat Tarawih.

Ketiga, penyembelihan hewan qurban. Hal kedua yang tampak paling menonjol dari masjid Al-Huda dibanding masjid lain di kecamatan Sumbang adalah tentang penyembelihan hewan qurban. Di masjid ini setiap moment hari raya 'Idul Adha bisa terkumpul 8 - 10 ekor sapi dan beberapa ekor kambing. Daging qurban dibagikan kepada seluruh warga di Brobot yang terdiri dari 5 RT dan 225 kepala keluarga dan setiap keluarga menerima daging sebanyak $2 \mathrm{~kg}$ ditambah dengan balungan dan jeroan. Selebihnya hasil kurban dibagikan kepada warga desa lain di sekitar dusun Brobot. Keempat, zakat mal, infak dan shadaqah (ZIS) dan kegiatan sosial. Meski belum maksimal namun kegiatan bidang ini sudah berjalan lancar. Untuk zakat mal sementara ini yang menjadi tulang punggungnya adalah keluarga Bani Singalani, terdiri dari 9 keluarga. Selain dari zakat mal, dana ZIS juga berasal dari infak. Untuk infak ini sumbernya dari kalangan yang lebih luas. Infak ini ada yang sifatnya rutin dan ada juga yang incidental. Infak rutin adalah infak yang dilakukan setiap hari saat menghadiri shalat jama'ah. Sedang infak incidental adalah infak yang dikeluarkan saat ada moment tertentu misalnya untuk menjenguk orang sakit atau melahirkan, untuk Sunatan Masal, peringatan hari besar Islam dan sebagainya.

Dana ZIS yang terkumpul secara rutin setiap bulan belum terlalu 


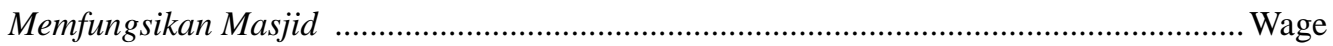

besar, baru sekitar Rp.1.600.000,-. Dana sebesar itu dikeluarkan secara rutin untuk biaya sekolah anak kurang mampu. Selain itu pada saat tertentu dana ZIS digunakan untuk bantuan modal usaha pedagang kecil atau buruh seperti untuk membelikan becak dan juga diberikan untuk buruh bangunan. Kegiatan sosial selain yang sudah disebutkan di atas (menjenguk orang sakit, melahirkan dan sunatan masal) adalah berupa pengobatan murah. Pengobatan diselenggarakan di klinik umum masjid Al-Huda khususnya diperuntukkan bagi warga kurang mampu dan orang lanjut usia (lansia). Kelima, tadarus al-Quran, shalat lail dan puasa sunah. Kegiatan tadarus al-Quran sudah lama menjadi kebiasaan orang dewasa jama'ah masjid Al-Huda. Kegiatan ini biasanya dilaksanakan setelah shalat Magrib. Di setiap keluarga para orang tua mempelopori tadarus al-Quran dan diikuti oleh anak-anak mereka yang sudah dewasa. Demikian juga untuk shalat lail dan puasa sunah. Jama'ah masjid Al-Huda membiasakan diri untuk melakukan shalat malam setiap malam dan melakukan shalat sunah setiap hari Senin dan Kamis.

Keenam, akhlak. Pendidikan Islam yang diberikan di Masjid Al-Huda telah melahirkan akhlak Islami yang cukup menonjol. Masyarakat Brobot dikenal memiliki akhlak yang luhur, karena sepanjang sejarahnya hampir tidak didengar adanya peristiwa negative dilakukan oleh warga Brobot. Jika masyarakat di desa lain banyak digemparkan oleh peristiwa kejahatan yang dilakukan warganya, atau tindakan asusila dilakukan oleh generasi mudanya, maka masyarakat Brobot terhindar dari hal semacam itu. Sebaliknya masyarakat sekitar menilai bahwa warga Brobot terkenal kealimannya. Tentunya terbentuknya akhlak semacam itu merupakan hasil dari pendidikan Islam yang dilakukan dengan baik; dimulai dari keteladanan orang tua, kemudian diikuti oleh generasi muda.

Tidak boleh lupa juga bahwa terbentuknya akhlak adalah dari pembiasaan ibadah yang istiqamah. Jadi lahirnya akhlak mulia ini selain faktor keteladanan dan didikan langsung, juga sebagai hasil dari peribadatan dan akidah yang mereka yakini. Jadi ibadah dan akidah yang kokoh sangat diyakini dapat melahirkan akhlak mulia. Hal ini bisa dilihat dari kajian tasawuf misalnya oleh Sekh Rahimuddin. Bahwa orang belajar tasawuf itu diawali dari belajar aqidah yang kokoh. Sebelum masuk ke kajian tasawuf para murid digembleng dulu tentang akidah yang lurus. Sebelum kajian akidah ini tuntas, mursyid belum akan mengajarkan tasawuf. Begitu ajaran akidah meresap ke dalam hati murid, maka mereka dengan sendirinya akan tumbuh keinginan yang kuat untuk beribadah dan mempraktekkan akhlak mulia.

3. Faktor-faktor yang Mempengaruhi Kesuksesan Pendidikan Islam di Masjid Al-Huda

Ada beberapa factor yang mempengaruhi kesuksesan pendidikan Islam yang dilakukan di masjid Al-Huda Brobot, yakni: pertama, faktor 


\section{Islãmadîna

sejarah. Pendidikan Islam di masjid Al-Huda sudah berjalan lama, yaitu semenjak tahun 1950 an. Pendidikan Islam sudah dimulai sebelum berdirinya masjid Al-Huda. Pada waktu itu pendidikan Islam dilaksanakan di pondok pesantren yang berlokasi di sebelah barat pekarangan yang kelak untuk komplek masjid Al-Huda. Tokoh pendidikannya waktu itu seorang kyai yang namanya dikeramatkan sampai sekarang, sebagai tokoh mistik, yaitu Mbah Nur Kalam. Belakang hari saat Kyai Jaelani didatangkan ke Brobot, pemahaman mistis-kejawen umat Islam di sana secara perlahan diluruskan dan digiring kearah pemahaman sesuai al-Quran dan al-Sunnah. Melalui masjid Al-Huda inilah kyai Jaelani melakukan pendidikan Islam yang sesuai dengan pemahaman kaum reformis.

Berdasar informasi yang bisa digali maka ajaran yang mula-mula diberikan kepada masyarakat adalah tentang aqidah. Dalam hal ini masyarakat disadarkan tentang pentingnya bidang ini. Dia mengajarkan bahwa aqidah merupakan fondasi keagaman umat. Melalui dalil-dalil yang diajarkannya secara perlahan umat bisa menerima, sehingga pemahaman mereka beralih dari mistis-kejawen ke pemahaman yang lurus. Setelah bidang aqidah ini selanjutnya materi yang disampaikan adalah bidang ibadah, khususnya shalat. Bidang ibadah yang diajarkan juga bersifat reformis. Kyai Jaelani berusaha meluruskan berbagai ibadah yang tidak sesuai tuntunan. Melalui penjelasan yang didukung oleh dalil-dalil yang meyakinkan masyarakat tergerak untuk melaksanakannya sehingga setiap datang waktu shalat umat Islam di sana selalu berusaha untuk melaksanakan shalat di masjid dengan berjama'ah dan ditambah dengan shalat sunah rawatib. Melalui penanaman motivasi yang kuat untuk beribadah ini maka umat Islam di sana menjadi orang Islam yang kuat ibadahnya. Setelah kyai Jaelani menghentikan dakwahnya di wilayah Sumbang, termasuk di Brobot, maka para muridnyalah yang melanjutkannya. Khusus di masjid Al-Huda Brobot maka tokoh paling getol yang menggerakkan pendidikan Islam adalah H. Narsum. Dia dibantu oleh murid kyai Jaelani lainnya, seperti Sahidi, SH, H. Sutrisno, Sarwono dan Waluyo. Setiap sepekan sekali mereka mendatangkan Amin Zaenuddin-murid Kyai Jaelani paling menonjol- dari desa Sumbang untuk mengisi pengajian rutin malam Sabtu.

Kedua, factor keteladanan. Bermula dari guru pertama yaitu kyai Jaelani yang merupakan sosok yang militant dalam berdakwah dan mengamalkan ajaran Islam, kemudian diikuti oleh oleh pelanjutnya, terutama H. Narsum. Dengan semangat yang menggelora dan anjuran yang setengah memaksa agar mereka mau mengamalkan apa yang diajarkannya, ditambah keteladanan yang ditampilkannya, menjadilah umat Islam di sekitar masjid Al-Huda sebagai sosok yang militant dalam mengamalkan berbagai ajaran Islam. Haji Narsum merupakan sosok guru yang berpembawaan serius. Selain itu dia juga dikenal sangat lurus dan wara'. Dia menjadi sosok yang konsisten dalam menlankan ajaran yang diberikan 


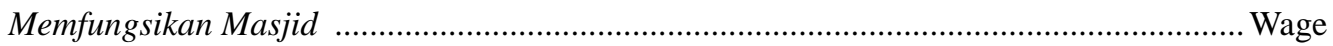

kepada jamaahnya. Jadi antara kata dan perbuatan selalu sejalan sehingga di mata masyarakat dia dipandang sebagai orang yang berwibawa dan dapat dicontoh.

Ketiga, factor metode. Metode pendidikan Islam diakui amat besar peranannya dalam keberhasilan atau kegagalan hasil pendidikan Islam. Berdasar hasil penelitian maka metode pendidikan Islam di masjid Al-Huda tergolong baik. Mereka menerapkan perpaduan antara metode lisan dan tindakan. Metode lisan dilakukan untuk menjelaskan materi keagamaan tertentu. Dalam metode lisan ini para guru yang mengajar di masjid Al-Huda selalu bersandar pada dalil. Mereka selalu membawa buku tertentu atau ringkasan materi yang diambil dari buku atau sumber lain. Ceramah yang mereka sampaikan biasanya cenderung mengarah ke serius dan tegas. Seloroh terkadang diselipkan dalam ceramah, namun sifatnya sangat jarang, jadi sekedar untuk selingan bila diperlukan.

Metode tindakan adalah berupa action atau langkah nyata, misalnya berupa ibadah mahdlah, pemberian dana ZIS kepada kaum lemah, pemberian daging qurban, sunatan masal yang diperuntukkan bagi anak-anak dari warga yang kurang mampu, pengobatan murah, pemberian bantuan untuk warga yang sakit atau melahirkan. Termasuk metode tindakan adalah kegiatan pawai keliling setiap memperingati Tahun Baru Islam. Tindakan seperti itu merupakan sesuatu yang sangat menyentuh kesadaran warga sehingga mereka tergerak hatinya untuk ikut mendukung apapun yang dilakukan oleh masjid Al-Huda. Termasuk metode tindakan yang dirasa ampuh untuk memompa semangat beramal adalah berupa amar ma'ruf-nahi munkar. Ketika ada jama'ah yang melakukan kekeliruan atau kendor semangatnya dalam mengamalkan agama maka ada guru yang secara langsung menindaknya. Misalnya ada jama'ah yang mengenakan kaos saat melakukan shalat di masjid, atau mengenakan baju berwarna-warni (selain warna putih), maka seketika itu juga yang bersangkutan ditegor di tempat. Contoh lain misalnya ada jama'ah yang tidak kelihatan di masjid saat pengajian atau shalat jama'ah, maka ada guru yang mendatangi ke rumahnya untuk menanyakan atau menegurnya. Dengan amar ma'ruf-nahi munkar seperti itu maka yang bersangkutan segera tersadar dari kekeliruannya dan langsung memperbaiki diri. Memang terkadang terjadi akibat teguran langsung di tempat bila yang terkena tindakan itu orang yang tidak tahan mental bisa berreaksi negatif. Namun biasanya bila ada guru yang melakukan tindakan kurang bijaksana ada tokoh lain yang mengingatkannya. Selain itu, bila ada jama'ah yang kemudian merasa tersinggung karena perlakukan yang kurang bijaksana ada tokoh agama yang akan mendekati untuk memberi nasehat agar tetap bersdabar dan menerima dengan ikhlas atas teguran yang diterimanya.

Keempat, kekompakan para tokoh. Dalam melakukan aneka kegiatan kegamaan masjid Al-Huda para tokohnya kompak. Mereka satu sama lain 


\section{Islãmadîna \\ JURNAL PEMIKIRAN ISLAM}

saling mendukung. Apa yang dipandang baik yang dicetuskan oleh para guru atau takmir masjid maka yang lain mendukungnya. Riak-riak kecil terkadang terjadi juga, misalnya ada guru yang terlalu keras menegor jama'ah yang agak kendor semangatnya dalam menjalankan agama. Kemudian jamaah yang ditegur sedikit berreaksi keras sehingga berakibat timbulnya percekcokan kecil. Setelah kabar atas kejadian tersebut menyeruak di tengah masyarakat muncul beberapa komentar, ada yang pro dan ada yang kontra terhadap sikap guru tersebut, terutama sikap yang muncul dari sesama tokoh. Namun hal itu segera bisa direm oleh tokoh lain yang bersikap netral. Jadi terasa sekali bahwa antara satu dan lain tokoh saling mengingatkan sehingga kekompakan sikap mereka tetap terpelihara.

\section{SIMPULAN}

Dari uraian di atas dapat diambil kesimpulan bahwa peranan masjid Al-Huda Brobot dalam pendidikan Islam antara lain pertama, dalam bentuk pengajian baik untuk orang dewasa, remaja dan anak-anak. Kedua, dalam bentuk khutbah, yaitu yang dilakukan pada waktu hari Jum'ah. Ketiga, pendidikan Islam berupa praktek pengamalan Islam dalam bentuk ibadah sosial dan syiar Islam. Ibadah sosial dalam ujud pemberian dana ZIS untuk kaum lemah, pembagian daging qurban, khitanan massal dan menjenguk orang sakit dan melahirkan. Sedangkan kegiatan syiar Islam ujudnya berupa pawai keliling dalam rangka memperingati tahun baru Islam.

Hasil yang diperoleh dari pendidikan Islam masjid Al-Huda Brobot adalah berupa ketekunan melaksanakan shalat Lima Waktu secara brjama'ah, puasa dan amaliyah Ramadlan, tadarus al-Quran, ZIS, ibadah qurban, shalat-shalat sunah dan puasa sunah, ibadah sosial. Dan tidak kalah pentingnya adalah akhlakul karimah. Faktor-faktor yang mempengaruhi keberhasilan pendidikan Islam di masjid Al-Huda pertama, factor sejarah, kedua factor keteladanan, ketiga, factor metode, serta keempat, factor kekompakan. Faktor sejarah berupa adanya fondasi yang kuat yang telah diletakkan oleh Mbah Nur Kalam dan Kyai Jaelani yang sudah lama dilakukan, yaitu semenjak tahun 1950 an. Faktor keteladanan maksudnya adanya teladan atau contoh dari para guru agama di sana, di mana mereka tidak hanya mengajak dengan lisan, namun mereka juga memberi contoh langsung dengan perbuatan. Sedangkan metode yang dipakai merupakan perpaduan antara lisan dan praktek. Faktor kekompakan, maksudnya tidak adanya konflik antar anggota takmir, para ustadz dan tokoh lainnya.. Dengan adanya perpaduan itu maka telah menopang kesuksesan pendidikan Islam di masjid Al-Huda. Dari uraian di atas juga tampak adanya kelemahan masjid Al-Huda, yaitu belum adanya perpustakaan. Padahal perpustakaan merupakan jantung sebuah lembaga pendidikan yang akan berfungsi untuk memompa intelektualitas para peserta didiknya. Sementara ini perpustakaan baru ada di rumah para tokoh agamanya, sehingga kebiasaan membaca belum terbangun di kalangan jama'ah masjid Al-Huda. Untuk itu ke depan perlu dipikirkan diadakannya perpustakaan masjid. Dengan melihat kisah 
sukses masjid Al-Huda sebagai lembaga pendidikan Islam di pedesaan, umat Islam dapat belajar dari factor-faktor pendukung kesuksesan pendidikan Islam di masjid tersebut, khususnya factor kegigihan tokohnya, keteladanan dan kekompakan.

\section{DAFTAR PUSTAKA}

Addeh, Damas and Sayida Fuad (2011), The Legal Framework of Mosque Building and Muslim Religious Affairs in Egypt: Towards a Strengthening of State control.

Ali, Maulana Muhammad (2007), Quran Suci: Terjemah dan Tafsir, Jakarta: Darul Kutubil Islamiyah

Ali, Suryadharma (2013), Paradigma Pesantren: Memperluas Horizon Kajian dan Aksi, Malang: UIN Maliki Press

Al-Maqdisi, Tartib 'Amali Zadahu Faidh Allahu Al-Husna (t.th.), Fath Arrahman Li Thalib Ayat al-Quran, Bandung: Maktab Dakhlan Indonesia

Anonim (2000), Ensiklopedi Hukum Islam, Jakarta: PT Ichtiar Baru Van Hoeve

Auliyah, R. (2014). Studi Fenomenologi Peranan Manajemen Masjid At-Taqwa dalam Pemberdayaan Ekonomi Masyarakat Bangkalan. Kompetensi (Competence: Journal of Management Studies), 8(1).

Farahati, Abbasali (2011), The Mosque as the First Political-Ideological Base in the Islamic Society, Journal of Politics and Law Vol. 4, No. 1

Glase, Cyril (2002) Ensiklopedi Islam, Jakarta: PT Raja Grafindo Persada

Hafidhuddin, Didin (2003), Islam Aplikatif, Jakarta: Gema Insani Press

Hasyim, Ahmad Umar (2007), Menjadi Muslim Kafah, Yogyakarta: Mitra Pustaka

Hentika, N. P. (2016). Menuju Restorasi Fungsi Masjid: Analisis Terhadap Handicap Internal Takmir Dalam Pengembangan Manajemen Masjid. Jurnal Manajemen Dakwah, 2(2).

Idi, Abdullah dan Toto Suharto, Revitalisasi Pendidikan Islam, (2006), Yogyakarta: Tiara Wacana

Ilyas, Yunahar (2002), Kuliah Akhlak, Yogyakarta: Lembaga Pengkajian dan Pengamalan Islam Universitas Muhammadiyah Yogyakarta

Isgandarova, Nazila (2009), Mosques as Communities of Memories vis-à-vis Muslim Identity and Integration in the European Union European, Journal of Economic and Political Studies

Muhaimin (2012), Paradigma Pendidikan Islam, Bandung: Remaja Rosdakarya

------- (2013).Rekonstruksi Pendidikan Islam: dari Paradigma Pengembangan, Manajemen Kelembagaan, Kurikulum hingga Strategi Pembelajaran, Jakarta: Rajagrafindo Persada,

Qomar, Mujamil (2014), Menggagas Pendidikan Islam, Bandung: Remaja Rosdakarya

Rahman, A. Hj. Abd, , A Mohamed, W.I.Wan Ahmad, F Adam, Z Mohamad (2011), Religious Educations Programs in The Rural Mosques, Trengganu, Malaysia, British Journal of Humanities and Social Sciences, Vol. 2 No. 2 Ramayulis (2012), Sejarah Pendidikan Islam: Napaktilas Perubahan Konsep, 


\section{Islãmadîna}

Filsafat dan Metodologi Pendidikan Islam dari Era Nabi SAW sampai Ulama Nusantara, Jakarta: Kalam Mulia

Shihab, M. Quraish (1996), Wawasan Al-Quran, Bandung: Mizan

Sofwan, R. (2013). Penguatan Manajemen Pemberdayaan Fungsi Masjid Al-Fattah di Kelurahan Krapyak Semarang. Dimas: Jurnal Pemikiran Agama untuk Pemberdayaan, 13(2), 315-334.

Tafsir, Ahmad (2013), Ilmu Pendidikan Islam, Bandung: Remaja Rosdakarya

'Ulwan, Abdullah Nasih (2012), Tarbiuah al-Aulad fi Al-Islam (Pendidikan Anak dalam Islam), Solo: Insan Kamil 